\title{
Vegetable cowpea as a source of cheap protein and an environmentally friendly crop for urban cities
}

\author{
B. Aliyu ${ }^{1} \&$ E. Wachap ${ }^{2}$ \\ ${ }^{1}$ Department of Agronomy, Taraba State University, Nigeria \\ ${ }^{2}$ College of Agriculture, Jalingo, Nigeria
}

\begin{abstract}
The world population is expected to grow from 5.7 billion in 1994 to 9.4 billion in 2050. More than half of the world's population (currently 7 billion) will be living in urban areas by the year 2015. This phenomenal increase in the global population and its attendant urbanization exerts extreme pressures on the earth systems through human activities, which now cause significant negative effects on the global cycles and systems. Urban gardening trends and some aspects of urban and peri-urban agriculture have been shown to be sustainable with a yield potential of up to $50 \mathrm{~kg}$ of fresh produce per square meter per year. However, the rate by which land is lost to urbanization, erosion, deforestation and desertification, especially in developing countries, calls for sophisticated, diverse and efficient production systems, which produce not only high yields and profit on an environmentally sustainable basis, but also produce foods that are nutritious enough to meet global food security indices. Vegetable cowpea, Vigna unguiculata, cultigroup Sesquipedalis is a vegetable cowpea par excellence, producing long succulent and green edible pods that are up to $0.7 \mathrm{~m}$ long, fresh edible pods of up to 4.1 tons per hectare and, above all, matures early, producing edible pods within 34 days of planting. It also performs excellently across varying agro-ecological zones from humid tropics to the dry savannah, making it a potentially global vegetable. The adoption of this vegetable variety in urban gardening (house hold gardens, roof tops, balconies, alley ways, road sides, etc.) and its incorporation as part of the design and planning initiatives for sustainable modern urban cities will guarantee an uninterrupted protein source to urban and
\end{abstract}


other families throughout the year either as fresh immature pods or as dry grains while also maintaining the integrity of the environment.

Keywords: urban cities, environment, climate change, planning, sustainable, vegetable cowpea, protein, food security, production.

\section{Introduction}

Cowpea Vigna unguiculata L. (Walp), belongs to the order Fabales, family Fabaceae, genus Vigna, Section Catiang, and subspecies unguiculata [1]. It is one of the most important food legume crops in the semiarid tropics covering Africa, Asia, southern Europe and Central and South America. A droughttolerant and warm-weather crop, cowpea is well-adapted to the drier regions of the tropics, where other food legumes do not perform well. It provides more than half the plant protein in the diets in many developing countries. It also contributes $60-70 \mathrm{~kg} \mathrm{~N} \mathrm{ha}^{-1}$ into the soil due to its nitrogen fixing properties and as a residue which benefits the succeeding crops [2]. This is in addition to the fact that it grows well in poor soils with more than $85 \%$ sand and with less than $0.2 \%$ organic matter and low levels of phosphorus [3]. It is also shade tolerant, and so is compatible as an intercrop.

Cowpea was cultivated on about 14.5 million hectares (ha) each year with an annual global production of 5.5 million tons [4]. Africa was responsible for $94 \%$ of this and Nigeria is the leading producer, producing 2.2 million tons in the year 2010. FAO, cited in IITA [5] website also reported 12.5 million hectares (ha), with an annual production of over 7.56 million tons worldwide.

Although cowpea is well adapted to the agro-ecosystems in which it is produced, the crop is affected by a wide range of biotic stresses- insect pests such as Aphids (Aphis craccivora), which attack the crop especially in the seedling stage, flower bud thrips (Megalurothrips sjostedti), pod borers (Maruca vitrata), a complex of pod sucking bugs, and the weevil, Callosobruchus maculatus [5]. Cowpea is also susceptible to a number of fungal, bacterial, and viral diseases such as Cercospora leaf spot, ashy stem blight, bacterial blight, blackeye cowpea mosaic potyvirus (BICMV), cowpea aphid-borne mosaic potyvirus (CABMV) and cowpea mosaic comovirus (CPMV). Cowpea plants are also attacked by the parasitic flowering plant Striga gesnerioides. All of these factors, singly or combined, are responsible for the low grain yield, estimated at approximately $350 \mathrm{~kg} / \mathrm{ha}$ that farmers in sub-Saharan Africa obtain from their cowpea fields.

It is important to note that although cowpea and vegetable cowpea (which is the focus of this study) belong to the same gene pool, the two are phenotypically different. Faris [6] reported that the cowpea originally arose from the domestication of Vigna unguiculata dekindtiana forms in West Africa. The postdomestication evolution of cultivated $V$. unguiculata has two sequential components-an African, followed by an Asian. Smart [7] noted that the African dimension embraced primary domestication and evolution of unguiculata form, and the Asiatic, the subsequent evolution of the cultigroups Cylindrica and Sesquipedalis. In the African context, the cowpea's role was predominantly that 
of a pulse although it may be exploited to a minor degree as a leafy vegetable. In Asia, during the process of domestication, the species was subjected to different selection pressures and, thus selection was practiced among the introduced unguiculata lines for its long, succulent and fleshy pod types, which eventually culminated in the Sesquipedalis cultivars and landraces [7, 8]. Thus the main distinguishing feature of vegetable cowpea from traditional cowpea is the pod length.

\subsection{Sustainable urban cities}

The environmental ramifications of human activities began to affect the functioning of major earth systems as far back as the period of the industrial revolution, progressing through World War II. Certain global environmental problems that arose in the late $20^{\text {th }}$ century highlighted the unprecedented extent of human impacts on the environment. These problems include climate change, depletion of the ozone layer and loss of biodiversity all brought about by population explosion that leads to land clearing, urbanization, deforestation, desertification, erosion, etc. These global impacts on the environment led to the concept of sustainability which involves three main interactive realms: environment, economic and social equity. Thus in talking about sustainability in general, the following basic principles are crucial:

1. Environmental health - the long term health and stability of natural systems are crucial to human society;

2. Social equity - the well being and stability of the society are important in creating a sustainable world;

3. Economic development - people's basic needs must first be met before they are expected to attend to the needs of the environment around them.

The above points summarized the concept of sustainability in general and, when applied to urban sustainable cities would denote cities that are able to meet their general needs in terms of development, food, health, infrastructure etc. without compromising the ability of future generations to meet their own needs [9].

As noted above, the extreme pressure on the earth systems has resulted from the doubling of our global population, quintupling of world economic output, and extreme disparities in the economic distribution [10]. The Consultative Group on International Agricultural Research, CGIAR [11], estimates that more than half of the world's population (currently 7.1 billion) would be living in urban areas by the year 2015. But even at present, global urbanization activities around the world just last year, 2013, alone has led to the loss of $3,726,312$ hectares (ha) of forests, land loss to soil erosion of up to 5,015,624 ha, $24,546,827,870$ tons of $\mathrm{CO}_{2}$ emissions and 8,598,313 ha of desertification around the world [12]. This is in addition to the fact that by next year (2015), about 26 cities in the world are expected to have a population of 10 million or 
more. This far reaching development makes it imperative to find more pragmatic ways of making our cities more sustainable than ever before.

The concept of urban and peri-urban agriculture (UPA) including urban gardening as a practise of cultivating, processing and distributing food in or around a village, town or city has been in existence for quite some time [13]. The United Nations Development Programme (UNDP) [14] has defined urban agriculture as "an industry that produces, processes and markets food and fuel, largely in response to the daily demand of consumers within a town, city or metropolis, on land and water dispersed throughout the urban and peri-urban area, applying intensive production methods, using and reusing natural resources and urban wastes to yield a diversity of crops and livestock". And, although an estimated 800 million people are currently engaged in some form of urban farming and gardening [15], a key issue is the food security aspect of the production system, that is, whether the food produced is nutritionally adequate, and is continuously available [16]. For our cities to be sustainable, in addition to the necessary general civilian infrastructure, UPA, including urban gardening should have a framework and/or design initiatives that should ensure that the production processes are not only sustainable but also leads to food security to our cities, that is, providing acceptable, nutritionally adequate food through local, non-emergency sources at all times especially for the poor urban populations and low income dwellers who spend up to $60 \%$ of their income on food [17]. Vegetable cowpea, Vigna unguiculata, cultigroup Sesquipedalis is a vegetable cowpea that belongs to the same gene pool with cowpea but, as noted earlier, differs from cowpea in that it has very long, succulent and fleshy pods. It is grown especially for those long succulent, fleshy and often, immature pods which are used as green vegetables. The pods can remarkably be eaten either raw if desired or otherwise cooked. The young leaves are also edible. In addition, the pods can be allowed to dry on the plant and harvested for dry grains from which many snacks and main meal dishes are produced. Thus all the plant parts that are used for food are nutritious, providing protein, vitamins and minerals that are the key elements to any sustainable food security programme. For instance the grain contains about $23-25 \%$ protein, $8-9 \%$ vitamins $A, B_{1}$ and $C ; 1.3 \%$ fibre and $50-67 \%$ carbohydrate [18]. The pods also mature early. However, despite the importance of vegetable cowpea, little is known about it in many countries especially in Nigeria, a leading producer of grain cowpea in the world. The few areas where the so-called vegetable cowpea is produced as in South-East Nigeria [19], the crop that is grown is that of cultigroup unguiculata, which is not a vegetable cowpea in its true sense. This work aims at the following:

1. To evaluate the performance of ten Chinese accessions of vegetable cowpea in Ganye city of Adamawa state, North-East Nigeria, and

2. To propose that the crop should be central in urban gardening efforts and that it should be incorporated in food security programmes as part of the design and planning for sustainable modern urban cities. 


\section{Materials and methods}

\subsection{Plant material and growing conditions}

Seeds of ten accessions of vegetable cowpea (cultigroup Sesquipedalis) were collected from the world cowpea germplasm maintained at the gene bank of the International Institute of Tropical Agriculture, IITA, Ibadan, Nigeria and used for the study. The accessions were Tropical Vigna unguiculata (TVu) 21, TVu 14861, TVu 14863, TVu 14865, TVu 14867, TVu 14868, TVu 14869, TVu 14871, TVu 14872 and TVu 14874. All the accessions were trailing or climbing (and thus stakes were applied one week after planting) with the exception of TVu 21 (the only accession from the Philippines) which had an erect growth habit. The materials were planted out in a randomized complete block design with three replicates for two years in Ganye town (latitude $8^{\circ} 30^{\prime} \mathrm{N}$ and longitude $11^{\circ} 50^{\prime} \mathrm{E}$ ) of Adamawa state in the North-Eastern part of Nigeria. The town has a mean annual rainfall of $1100 \mathrm{~mm}$ to $1600 \mathrm{~mm}$ and it is located in Southern Guinea Savanna zone. The field was measured $37.5 \mathrm{~m}$ in length and $27 \mathrm{~m}$ width. This gave a total area of $1012.5 \mathrm{~m}^{2}$. Each replicate consisted of ten plots making a total of 30 plots per year. Each plot measured $8 \mathrm{~m}$ in length and $5 \mathrm{~m}$ width. Pathways of $0.5 \mathrm{~m}$ between plots and $1 \mathrm{~m}$ between replications were provided. The seeds were hand planted at a row spacing of $1 \mathrm{~m}$ and plant spacing of $1 \mathrm{~m}$. Each plot was planted with eight seeds per row in five rows, giving 40 plants per plot. Weeding was done manually with a hoe and staking was done 2-3 weeks after emergence. The pods ripe unevenly and thus five harvests (hand pickings) were conducted.

\subsection{Characterization}

Data were recorded for each of the ten accessions on number of days to first flower, number of days to first pod, terminal leaflet length $(\mathrm{cm})$, pod length $(\mathrm{cm})$, number of seeds per pod, fresh pod weight (ton/ha), number of pods per plant (five pickings), 100 seed weight (g) and grain yield per plot (kg).

\subsection{Biometrical procedures}

Analysis of variance was performed on the measurements of each trait on individual plants and on year basis. Each trait was computed on plot means. The means for the two years were pooled as described by Singh and Choudhary [20]. Means were separated by using Duncan's Multiple Range Test (DMRT) as described by Duncan [21] for both individual and combined analysis of variance.

\section{Results and discussion}

Significant differences existed in the mean performance of the ten accessions for all the nine traits of the ten accessions of the vegetable cowpea (Table 1). The genotypes also interacted significantly with the year of production. This is due to 
the wide annual range in the amount of rainfall in the area. TVu 14872 and TVu 14869 produced the longest pods that exceed $67 \mathrm{~cm}$ (Table 2, Fig. 1). This figures exceeded the average pod length of $37.23 \mathrm{~cm}$ reported by Hazra et al. [22] from India, $16.2 \mathrm{~cm}$ reported by Uguru [19] from Nigeria and $35.02 \mathrm{~cm}$ by IITA characterization also in Nigeria. Interestingly, Hazra et al. [22], Uguru [19] and IITA characterization were all conducted in the humid tropics of India, humid tropics of South East Nigeria, and humid tropics of South West Nigeria, respectively. But the present evaluation was carried out in the dry Southern Guinea Savanna zone of North-East Nigeria. The present study also recorded the earliest flowering time of 31.2 days after planting (TVu 14861) to the 46.51 days of Hazra et al. [22] and 42 days of IITA characterization.

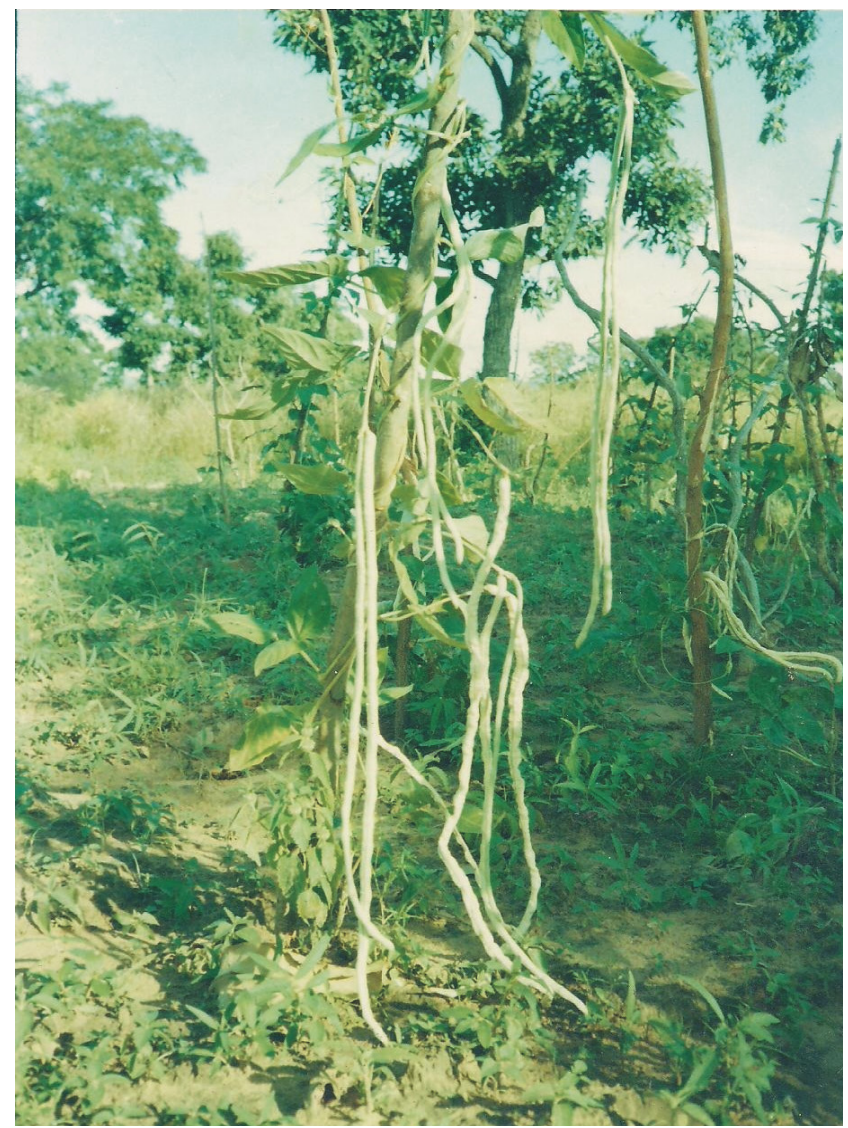

Figure 1: TVu 14782 accession of vegetable cowpea.

The results indicate that the accessions would perform better in the dry Savanna areas characteristic of northern Nigeria. However, pod length and fresh pod weight had the highest phenotypic variance, while pod length had, in 
addition, the highest environmental variance (Table 3). The average number of pods (7.9) produced per plant (Table 3 ) was far less than the 52 pods recorded by Uguru [19] and 18.86 pods recorded by Hazra et al. [22]. The figure (7.9 pods) of the current evaluation is closer to that of the latter author (18.86 pods) because the materials utilized were from the same cultivar group Sesquipedalis, which is characterized with the longest pods within the cultigroups. The 52 pods reported by Uguru [19] were because the materials utilized by the author are from cultigroup Unguiculata whose characters are midway between cultigroup Biflora and cultigroup Sesquipedalis. TVu 14871 recorded the highest fresh pod weight of 4.1 tons per ha. This falls within the upper limit of the yield range of 1.5-6.0 $\mathrm{t} / \mathrm{ha}$ of vegetable cowpea reported by Tindall [23]. TVu 14872 and $\mathrm{TVu} 14869$ had no significant difference in their flowering time, pod length, number of pods per plant, 100 seed weight and grain yield, performing best in those characters than the other accessions.

From the above results, it is obvious that two accessions - TVu 14872 and $\mathrm{TVu} 14869$ would be easily recommended to farmers for adoption - producing fleshy, edible pods in just about 34 days after planting, having the longest pods, more seeds per pod and also highest dry grain yield. The crop has high protein content $(23-25 \%)$ as well as other important nutrients and this is the most important factor to consider in making food security related policies. Indeed the definition of UPA by the UNDP [14] did not reconcile aspects of food security, regional health and application of grassroots organizations, Wikipedia [24]. In its own definition of UPA, CAST [25], maintains that in addition to aspects recognised by UNDP [14], UPA should include other aspects such as recreation and leisure, economic vitality and business entrepreneurship, land scape beautification, environmental restoration and remediation together with individual health and well being, and community health and well being, the last two hinging on food security aspects which implies the quality of food produced and consumed in urban cities. In planning modern urban cities, therefore, the above model of urban agriculture better fits the current scope of design of sustainable cities. Moreover, the nutrient content of vegetable cowpea produced in urban household gardens is higher because of the decrease in time between production and consumption. According to Bellows, et al. [26], a 30-50\% nutrient loss can take place between 5-10 days it can take to travel from the farm to the table.

Because the crop can be easily produced in household gardens, roof tops, alleyways, balconies, etc. and within a short time, vegetable cowpea can reduce a city's carbon footprint by reducing the amount of transport that occurs to deliver the goods to the consumer. The crop can also help in carbon sequestration since it can be grown year round in the gardens because the plants can continue to absorb carbon dioxide $\left(\mathrm{CO}_{2}\right)$ from the atmosphere and release breathable oxygen. By extension, the crop can also be said to contribute in reducing ozone concentration, noise pollution, entrepreneurial activities, job opportunities, reduction in food costs, increase income and overall social and emotional wellbeing. 


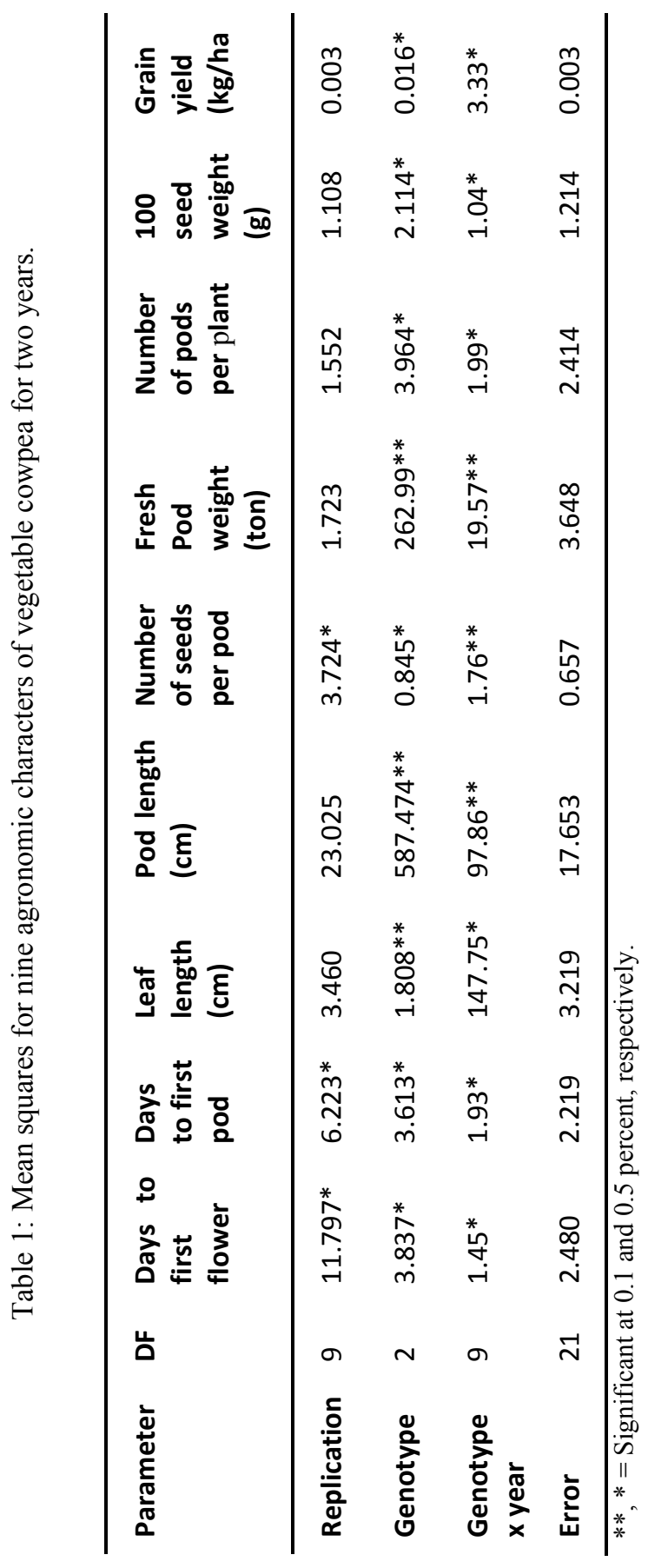







Table 3: $\quad$ Means and ranges and genotypic, phenotypic and environmental variances for nine characters of vegetable cowpea.

\begin{tabular}{|c|c|c|c|c|c|}
\hline Character & Mean & Range & $\begin{array}{l}\text { Genotypic } \\
\text { variance }\end{array}$ & $\begin{array}{l}\text { Phenotypic } \\
\text { variance }\end{array}$ & $\begin{array}{l}\text { Environmental } \\
\text { variance }\end{array}$ \\
\hline $\begin{array}{l}\text { Days to first } \\
\text { flower }\end{array}$ & 32.61 & $30.60-34.80$ & 3.21 & 3.69 & $0.36 \pm 0.11$ \\
\hline $\begin{array}{l}\text { Days to first } \\
\text { pod }\end{array}$ & 34.23 & $32.00-36.80$ & 2.94 & 3.47 & $0.39 \pm 0.13$ \\
\hline $\begin{array}{l}\text { Terminal } \\
\text { leaflet length } \\
\text { (cm) }\end{array}$ & 11.51 & $7.80-13.80$ & 6.16 & 18.20 & $4.89 \pm 1.55$ \\
\hline $\begin{array}{l}\text { Pod length } \\
\text { (cm) }\end{array}$ & 47.45 & $18.90-70.10$ & 32.05 & 32.49 & $6.42 \pm 2.03$ \\
\hline $\begin{array}{l}\text { Number of } \\
\text { seeds per } \\
\text { pod }\end{array}$ & 16.85 & $14.00-18.50$ & 5.44 & 6.71 & $0.39 \pm 0.31$ \\
\hline $\begin{array}{l}\text { Fresh pod } \\
\text { weight } \\
\text { (ton/ha) }\end{array}$ & 15.42 & $6.80-42.10$ & 61.96 & 62.20 & $0.71 \pm 0.22$ \\
\hline $\begin{array}{l}\text { Number of } \\
\text { pods per } \\
\text { plant }\end{array}$ & 7.90 & $6.60-9.20$ & 7.45 & 8.36 & $0.90 \pm 0.03$ \\
\hline $\begin{array}{l}100 \text { seed } \\
\text { weight }(\mathrm{g})\end{array}$ & 13.05 & $11.60-15.40$ & -0.49 & 10.35 & $1.83 \pm 0.58$ \\
\hline $\begin{array}{l}\text { Grain yield } \\
\text { (kg) }\end{array}$ & 0.37 & $0.23-0.49$ & 14.68 & 18.95 & $0.00 \pm 0.00$ \\
\hline
\end{tabular}

\section{References}

[1] Maréchal, R., Mascherpa, J.M. \& Stainier, F. 1978. Etude taxonomiqued'un groupe complexe d'especes des genres Phaseolus et Vigna (Papilionaceae) sur la base de donnees morphologiques et polliniques, traitees par l'analyse infomatique. Boissiera, 28: 184-188.

[2] Rachie, K.O. 1985. Introduction. In Cowpea: Research, Production and Utilization. Singh, S.R. and K.O. Rachie (eds). John Wiley.

[3] Singh, B., Ajeigbe, H.A., Tarawali, S.A., Fernandez-Rivera, S. \& Abubakar, M. 2003. Improving the production and utilization of cowpea as food and fodder. Field Crops Research, 84: 169-150.

[4] Consultative Group on International Agricultural Research, CGIAR, 2010. Annual Report. www.cgiar.org. 
[5] International Institute of Tropical Agriculture, IITA, 2009. Annual Report and Research Highlights. Ibadan, Nigeria.

[6] Faris, D.G. 1965. The origin and evolution of the cultivated forms of Vigna sinensis. Canadian Journal of Genetics and Cytology, 7: 443-452.

[7] Smart, J. 1990. Grain Legumes: Evolution and Genetic Resources. Cambridge University Press, Cambridge. 397p.

[8] Steele, W.M. \& Mehra, K.L. 1980. Structure, evolution and adaptation to farming systems and environment in Vigna. In Advances in Legume Sciences. Summerfield, R.J. and A.H. Bunting (eds). London, pp. 393-404.

[9] WCED, 1987. World Commission on Environment and Development (Gro Harlem Bruntland, Chair). Our Common Future. Oxford University Press, Oxford.

[10] Posted, S. 1994. Carrying Capacity: The Earth's Bottom Line. In: Beyond the Numbers: A Reader on Population, Consumption and the Environment. L. Anne Mazur (Ed.), Island Press, Washington DC.

[11] Consultative Group on International Agricultural Research (CGIAR). 1999. CGIAR News.

[12] Worldometers, 2013. Real time World Statistics. www.worldometers.htm.

[13] Bailkey, M. \& Nasr, J. 2000. From Brownfields to Greenfields: Producing Food in North American Cities. Community Food Security News.

[14] UNDP, 1996. Urban Agriculture: Food, Jobs and Sustainable Cities. United Nations Development Programme, New York. Smith J., Ratta, A. \& Nasr, J. (eds.).

[15] Food and Agriculture Organization of the United Nations, FAO, 1999. Committee on Agriculture (COAG), 25-26 January, Rome, Italy.

[16] Community Food Security Coalition, CFSC, 2003. www.foodsecurity.org. retrieved 2013-04 01.

[17] IDRC/UN-HABITAT, 2003. Guidelines for Municipal Policymaking on Urban Agriculture. In: Urban Agriculture: Land Management and Physical Planning. 13(1).

[18] Quin, F.M. 1997. Introduction. In Advances in Cowpea Research. Copublication of International Institute of Tropical Agriculture (IITA) and Japan International Research Center for Agricultural Sciences (JIRCAS). Singh, B.B., Mohan Raj, D.R., Dashiel, K.E. \& Jackai, L.E.N. (eds.) IITA, Ibadan, Nigeria.

[19] Uguru, M.I. 1996. A note on the Nigerian Vegetable cowpea. Gen. Res. Crop Evol., 43: 125-128.

[20] Singh, R.K. \& Choudhary, B.D. 1985. Biometrical Methods in Quantitative Genetic Analysis. Kalyani Publishers, New Delhi, India, pp. 69-78.

[21] Duncan, D. 1955. Multiple ranges and multiple F-tests. Biometrics, 11: $1-42$.

[22] Hazra, P., Das, P.K. \& Som, M.G. 1993. Characterization of the three cultigroups of cowpea, Vigna unguiculata (L. Walp). Crop Res. 6: 465-474. 
[23] Tindall, H.D. 1986. Vegetables in the Tropics. Macmillan. London. p. 298.

[24] Wikipedia, The Free Online Encyclopaedia. https:/www.wikipedia.org/.

[25] Council for Agricultural Science and Technology, CAST, 2003. Urban and Agriculture Communities: Opportunities for Common Ground. Butler, L. \& Moronek, D.M. (eds). Ames, Iowa. Retrieved 2013.

[26] Bellows, A.C., Anne, C., Brown, K. \& Smith, J. 2013. Health Benefits of Urban Agriculture. Community Food Security Coalition, North American Initiatives. www.foodsecurity.org Retrieved 2013-04-01. 